\title{
Single versus double intrauterine insemination to assess the relevance of double intrauterine insemination: a prospective, randomized multicentric study
}

\section{Deepak Patil*}

Department of Obstetrics and Gynecology, Command Hospital Air Force, Bangalore, Karnataka, India

Received: 03 May 2021

Accepted: 18 May 2021

*Correspondence:

Dr. Deepak Patil,

E-mail: deepakaarav6@gmail.com

Copyright: () the author(s), publisher and licensee Medip Academy. This is an open-access article distributed under the terms of the Creative Commons Attribution Non-Commercial License, which permits unrestricted non-commercial use, distribution, and reproduction in any medium, provided the original work is properly cited.

\begin{abstract}
Background: Intrauterine insemination (IUI) is a widely used tool as initial treatment option for infertile couples. Being a non-invasive, outpatient department (OPD) based procedure it serves as first modality of assisted reproductive technique. Overtime various modifications in stimulation protocol, sperm preparation techniques and variation in timing has been attempted to improve upon the success rates.

Methods: We conducted a multicentric, prospective randomized study and assessment of data of double IUI at three tertiary care centers of armed forces. The data was evaluated to study the patient parameters and various factors affecting the success rate of IUI.

Results: We found that duration of infertility, age of couple and body mass index (BMI) are inversely related to success of IUI cycles. Double IUI increases the success rate in borderline male factor infertility, ladies with normal BMI and in cases of secondary infertility with previous live issue. In donor IUI cycles there is a positive correlation with sperm parameters and benefit from double insemination.

Conclusions: Double IUI can be offered to selected couples to improve upon the success rate of IUI cycle.
\end{abstract}

Keywords: Insemination, Double intrauterine insemination, Ovulation

\section{INTRODUCTION}

Intrauterine insemination (IUI) is an efficient and economic treatment modality for infertility. It forms the first line of treatment for unexplained infertility, anovulatory infertility and mild male factor infertility. The only essential factor for providing IUI being documented patent tube. ${ }^{1}$. IUI also serves as primary method of treatment for various ejaculatory and coital problems.

With advances in ART, improving success rate of this less expensive and invasive seems to be overlooked. Intrauterine insemination as a treatment modality evolved over many years. Since identification of spermatozoa by Anton van Leeuwenhoek in 1678 numerous researchers have contributed to this modality of treatment. Initially it was restricted to Farm animals. First documented artificial Insemination in human was done in 1770 s by John Hunter for patient with severe hypospadiasis. Over years refinement of techniques has made this treatment option being, so widely available. Inspite of various treatments evolving over time IUI remains the oldest and most commonly used treatment option for infertile couples. ${ }^{2}$

Being a noninvasive and outpatient department (OPD) based procedure, IUI often serves as a first treatment modality for numerous etiologies of infertility.

The objective of the study was to assess the relevance of double Intrauterine Insemination over single insemination. And also to identify relevant subset of patient specially benefitted. 


\section{METHODS}

This was a multicentric prospective randomized study to assess records of patient provided with single and double insemination over one year. For uniformity of protocol in the various centre's drugs, injections, media and disposables were standardized. Sperm preparation methods and timing of IUI was also standardized to be followed.

Following a basic work up of infertile couple which included blood sugar levels, thyroid function test, serum prolactin levels, anti-Müllerian hormone (AMH) titers and viral markers patient were called on D2-5 from onset of menses for a transvaginal scan. Those patients meeting the exclusion and exclusion criteria were enrolled in the study. Randomization was achieved by alternating single and double IUI in consecutive ovulation induction cycles. No more than six IUI cycles were provided to the patient.

The design of the study was a prospective randomized study. The location of the study was multicentric: southernstar ART centre, Pune; Basistha ART centre, Guwahati; and Navakriti ART centre, Bangalore. The duration of the study was one year i.e. from 01 January 2019 to 31 December 2019.

\section{Sample size}

The study consisted of all patients undergoing IUI.

Patients with bilateral patent tubes with duration of infertility below ten years were included in the study. Euthyroid level and correction of serum prolactin and sugar levels was ensured before taking up the patient in this study.

Couples with severe male factor infertility defined as sperm count below 10 million per $\mathrm{ml}$ and progressive motile spermatozoa below $32 \%$ were not included in the study. Ladies with genital tuberculosis and obvious pelvic pathology like endometrioma, ovarian cyst or hydrosalphinx were excluded from the study.

After recruiting the couple in this study, tablet fertomid containing clomiphene citrate $100 \mathrm{mg}$ from Cipla ltd. was used for polyfollicular growth. The drug was given orally for five days from day 2-5 from onset of menses. This was followed by three doses of injection gonal $\mathrm{F}$ containing follitropin alpha from Merck Pharmaceuticals, 75 IU sc. Following this the patient was re-evaluated by TVS and personalize stimulation protocol was followed based on ovarian response and AMH levels. When lead follicle reached $18 \mathrm{~mm}$, injection $\mathrm{HCG} 10,000 \mathrm{IU}$ was given as trigger for ovulation. IUI was performed 12-16 hours and 36-40 ours post ovulation trigger.

Semen preparation was done using double density gradient method. The liquefied semen sample was overlaid, over a double density gradient of ORIGIO gradient 40/80 from cooper surgical. It contained silane coated colloidal silica particles with HEPES as buffering agent in a conical bottom $15 \mathrm{ml}$ tube. The conical tube is centrifuged at 1500 rotations per minute (rpm) for $15 \mathrm{~min}$. The resultant pellet was resuspended in $5 \mathrm{ml}$ of hydroxyethyl piperazineethanesulfonic acid (HEPES) based media and centrifuged at $800 \mathrm{rpm}$ for $5 \mathrm{~min}$. After removing the supernatant, the pellet was overlaid with $1 \mathrm{ml}$ of bicarbonate based media for 30 min to harvest the swim up sperms. For swim up universal in-vitro fertilization (IVF) medium from Cooper surgical was used.

Luteal support was provided with tablet duphastone from Abott Pharmaceuticals containing dydrogesterone $10 \mathrm{mg}$ twice a day for 3 weeks following IUI. Pregnancy rate was defined as a positive urine pregnancy test. Chi square test was used for data analysis.

\section{RESULTS}

\section{Patient characteristics (age, duration of infertility and body mass index (BMI))}

With increase in age chances of success falls. In both single and double insemination pregnancy rate falls four folds in patients in age above 40 years as compared to ladies in age group 30-35 years. More than half of all IUI conceptions in both single and double insemination occurred in couple with less than five years of duration of infertility. Nearly $70 \%$ of all pregnancies occurred in ladies with normal BMI. Overweight and obese patients had significantly lower chances of conceiving with both single and double insemination (Table 1-3).

Table 1: Age of female partner.

\begin{tabular}{|c|c|c|c|c|c|c|}
\hline Age (years) & $\begin{array}{l}\text { Single } \\
\text { IUI }\end{array}$ & $\begin{array}{l}\text { Number of } \\
\text { pregnancies }(\%) n=21\end{array}$ & $\begin{array}{l}\text { Pregnancy } \\
\text { rate }(\%)\end{array}$ & $\begin{array}{l}\text { Double } \\
\text { IUI }\end{array}$ & $\begin{array}{l}\text { Number of } \\
\text { pregnancies }(\%) n=34\end{array}$ & $\begin{array}{l}\text { Pregnancy } \\
\text { rate }(\%)\end{array}$ \\
\hline$<25$ & 49 & $1(4)$ & 2 & 43 & $2(5)$ & 4 \\
\hline $25-30$ & 81 & $8(38)$ & 9 & 61 & $17(50)$ & 27 \\
\hline 30-35 & 73 & $9(42)$ & 12 & 81 & $12(35)$ & 14 \\
\hline $35-40$ & 26 & $2(9)$ & 7 & 27 & $2(6)$ & 7 \\
\hline$>40$ & 31 & $1(4)$ & 3 & 31 & $1(3)$ & 2 \\
\hline Total & 260 & 21 & & 243 & 34 & \\
\hline
\end{tabular}


Table 2: Duration of infertility.

\begin{tabular}{|lllllll|}
$\begin{array}{l}\text { Years of } \\
\text { infertility }\end{array}$ & $\begin{array}{l}\text { Single } \\
\text { IUI }\end{array}$ & $\begin{array}{l}\text { Number of pregnancies } \\
(\boldsymbol{\%}) \mathbf{n = 2 1}\end{array}$ & $\begin{array}{l}\text { Pregnancy } \\
\text { rate }(\boldsymbol{\%})\end{array}$ & $\begin{array}{l}\text { Double } \\
\text { IUI }\end{array}$ & $\begin{array}{l}\text { Number of pregnancies } \\
(\boldsymbol{\%}) \mathbf{n}=\mathbf{3 4}\end{array}$ & $\begin{array}{l}\text { Pregnancy } \\
\text { rate }(\boldsymbol{\%})\end{array}$ \\
\hline $\mathbf{1 - 5}$ & 123 & $14(66)$ & 11 & 113 & $19(52)$ & 15 \\
\hline $\mathbf{5 - 1 0}$ & 91 & $7(33)$ & 7 & 89 & $15(41)$ & 15 \\
\hline Total & 260 & 21 & & 243 & 34 & \\
\hline
\end{tabular}

Table 3: BMI of female partner.

\begin{tabular}{|lllllll|}
\hline BMI $\left(\mathrm{kg} / \mathrm{m}^{2}\right)$ & $\begin{array}{l}\text { Single } \\
\text { IUI }\end{array}$ & $\begin{array}{l}\text { Number of pregnancies } \\
(\boldsymbol{\%}) \mathbf{n = 2 1}\end{array}$ & $\begin{array}{l}\text { Pregnancy } \\
\text { rate }(\boldsymbol{\%})\end{array}$ & $\begin{array}{l}\text { Double } \\
\text { IUI }\end{array}$ & $\begin{array}{l}\text { Number of pregnancies } \\
(\boldsymbol{\%}) \mathbf{n}=\mathbf{3 4}\end{array}$ & $\begin{array}{l}\text { Pregnancy } \\
\text { rate }(\%)\end{array}$ \\
\hline $\mathbf{1 1 8 . 5}$ & 83 & $3(14)$ & 4 & 29 & $2(5)$ & 6 \\
\hline $\mathbf{1 8 . 5 - 2 4 . 9}$ & 111 & $15(71)$ & 13 & 81 & $24(70)$ & 29 \\
\hline $\mathbf{2 5 - 2 9 . 9}$ & 59 & $2(9)$ & 3 & 54 & $7(20)$ & 12 \\
\hline$>\mathbf{3 0}$ & 67 & $1(4)$ & 1 & 79 & $1(2)$ & 1 \\
\hline Total & 260 & 21 & & 243 & 34 & \\
\hline
\end{tabular}

Table 4: Type of infertility.

\begin{tabular}{|lllllll|}
\hline Type & $\begin{array}{l}\text { Single } \\
\text { IUI }\end{array}$ & $\begin{array}{l}\text { Number of } \\
\text { pregnancies (\%) } \\
\mathbf{n = 2 1}\end{array}$ & $\begin{array}{l}\text { Pregnancy } \\
\text { rate (\%) }\end{array}$ & $\begin{array}{l}\text { Double } \\
\text { IUI }\end{array}$ & $\begin{array}{l}\text { Number of } \\
\text { pregnancies }(\%)\end{array}$ & $\begin{array}{l}\text { Pregnancy } \\
\text { rate }(\%)\end{array}$ \\
\hline Primary infertility & 111 & $4(19)$ & 3 & 75 & $6(17)$ & 8 \\
\hline Previous abortions & 91 & $8(38)$ & 8 & 97 & $15(44)$ & 15 \\
\hline Previous live births & 67 & $9(42)$ & 13 & 71 & $13(34)$ & 18 \\
\hline Total & 260 & 21 & & 243 & 34 & \\
\hline
\end{tabular}

Table 5: Previous IUI cycles.

\begin{tabular}{|lllllll|}
\hline IUI cycles & $\begin{array}{l}\text { Single } \\
\text { IUI }\end{array}$ & $\begin{array}{l}\text { Number of pregnancies } \\
(\%) \mathbf{n = 2 1}\end{array}$ & $\begin{array}{l}\text { Pregnancy } \\
\text { rate }(\%)\end{array}$ & $\begin{array}{l}\text { Double } \\
\text { IUI }\end{array}$ & $\begin{array}{l}\text { Number of pregnancies } \\
(\%) \mathbf{n = 3 4}\end{array}$ & $\begin{array}{l}\text { Pregnancy } \\
\text { rate }(\%)\end{array}$ \\
\hline $\begin{array}{l}\text { First or second } \\
\text { IUI }\end{array}$ & 97 & $11(52)$ & 11 & 91 & $15(44)$ & 16 \\
\hline $\begin{array}{l}\text { Third/fourth } \\
\text { IUI cycles }\end{array}$ & 89 & $6(28)$ & 6 & 73 & $17(50)$ & 23 \\
\hline $\begin{array}{l}\text { Fifth } \text { or } \text { sixth } \\
\text { IUI cycles }\end{array}$ & 43 & $3(14)$ & 6 & 75 & $2(5)$ & 2 \\
\hline$>$ Six IUI cycle & 31 & $1(4)$ & 3 & 4 & 0 & 0 \\
\hline Total & 260 & 21 & & 243 & 34 & \\
\hline
\end{tabular}

Table 6: Prewash sperm count.

\begin{tabular}{|lllllll|}
\hline $\begin{array}{l}\text { Pre wash sperm } \\
\text { count (millions) }\end{array}$ & $\begin{array}{l}\text { Single } \\
\text { IUI }\end{array}$ & $\begin{array}{l}\text { Number of pregnancies } \\
(\%) \mathbf{n = 2 1}\end{array}$ & $\begin{array}{l}\text { Pregnancy } \\
\text { rate }(\boldsymbol{\%})\end{array}$ & $\begin{array}{l}\text { Double } \\
\text { IUI }\end{array}$ & $\begin{array}{l}\text { Number of pregnancies } \\
(\boldsymbol{\%}) \mathbf{n = 3 4}\end{array}$ & $\begin{array}{l}\text { Pregnancy } \\
\text { rate }(\%)\end{array}$ \\
\hline $\mathbf{1 5 - 2 0}$ & 29 & $2(9)$ & 6 & 81 & $19(55)$ & 23 \\
\hline $\mathbf{2 0 - 2 5}$ & 47 & $3(14)$ & 6 & 23 & $5(14)$ & 21 \\
\hline $\mathbf{2 5 - 3 0}$ & 81 & $7(33)$ & 8 & 43 & $1(29)$ & 3 \\
\hline $\mathbf{3 3 0}$ & 103 & $9(42)$ & 8 & 96 & $9(26)$ & 9 \\
\hline Total & 260 & 21 & & 243 & 34 & \\
\hline
\end{tabular}

\section{Patient history (type of infertility and history of IUI)}

In our study secondary infertility was found to be a reliable and significant prognostic indicator for success rate of IUI. We found chances of conceiving nearly doubles in patients with secondary infertility as compared with patients with primary infertility. In cases of primary infertility the number of total pregnancies was $20 \%$ as compared to mean of $40 \%$ for ladies with secondary infertility. This was seen for both single and double insemination. Chances of conception were maximum in initial IUI cycles as compared to later IUI cycles. First/second IUI cycle accounted for 52 and $44 \%$ of conception as compared to 14 and $5 \%$ of total conceptions in fifth and six IUI cycles 
in single and double insemination respectively (Table 4 and 5).

\section{Male factor assessment (prewash count and motility, post wash sperm count)}

The seminal characteristics were directly proportional to outcome of IUI cycles in single insemination. Pregnancy rate was $23 \%$ for prewash count of $15-20 \mathrm{million} / \mathrm{ml}$ in double insemination as compared to $6 \%$ for single insemination. Sperm count of 15-20 million/ml accounted for $55 \%$ of total pregnancies in double insemination. In single insemination, a grade IV motility of more than $80 \%$ gave us a pregnancy rate of $9 \%$. A prewash motility of 20-
$40 \%$ grade IV gave us $17 \%$ pregnancy rate in double insemination as compared to $8 \%$ in single insemination. Post wash semen characteristics showed significantly higher number of pregnancy in sperm count category of $15-20 \mathrm{~m}$ in double insemination as compared to single insemination. Post wash sperm count below $15 \mathrm{million} / \mathrm{ml}$ gave a poor pregnancy rate of $4 \%$ (Table 6-8).

\section{Donor IUI}

In donor IUI, double insemination definitely showed benefit. We got a pregnancy rate of $22 \%$ for double insemination as compared to $14 \%$ in single insemination (Table 9).

Table 7: Grade IV motile sperm percentage.

\begin{tabular}{|lllllll|}
\hline $\begin{array}{l}\text { Grade IV } \\
\text { motile sperm } \\
\text { percentage }\end{array}$ & $\begin{array}{l}\text { Single } \\
\text { IUI }\end{array}$ & $\begin{array}{l}\text { Number of pregnancies } \\
(\%) \mathbf{n = 2 1}\end{array}$ & $\begin{array}{l}\text { Pregnancy } \\
\text { rate }(\boldsymbol{\%})\end{array}$ & $\begin{array}{l}\text { Double } \\
\text { IUI }\end{array}$ & $\begin{array}{l}\text { Number of pregnancies } \\
(\boldsymbol{\%}) \mathbf{n}=\mathbf{3 4}\end{array}$ & $\begin{array}{l}\text { Pregnancy } \\
\text { rate }(\boldsymbol{\%})\end{array}$ \\
\hline$<\mathbf{2 0}$ & 4 & 0 & 0 & 21 & 0 & 0 \\
\hline $\mathbf{2 0 - 4 0}$ & 23 & $2(9)$ & 8 & 103 & $18(52)$ & 17 \\
\hline $\mathbf{4 0 - 6 0}$ & 41 & $3(14)$ & 7 & 71 & $11(32)$ & 15 \\
\hline $\mathbf{6 0 - 8 0}$ & 119 & $9(42)$ & 7 & 15 & $2(5)$ & 9 \\
\hline$>\mathbf{8 0}$ & 73 & $7(33)$ & 9 & 33 & $3(8)$ & \\
\hline Total & 260 & 21 & & 243 & 34 & \\
\hline
\end{tabular}

Table 8: Post wash sperm count.

\begin{tabular}{|lllllll|}
\hline $\begin{array}{l}\text { Post wash } \\
\text { sperm count } \\
(\mathbf{m} i l l i o n s)\end{array}$ & $\begin{array}{l}\text { Single } \\
\text { IUI }\end{array}$ & $\begin{array}{l}\text { Number of pregnancies } \\
(\boldsymbol{\%}) \mathbf{n = 2 1}\end{array}$ & $\begin{array}{l}\text { Pregnancy } \\
\text { rate }(\boldsymbol{\%})\end{array}$ & $\begin{array}{l}\text { Double } \\
\text { IUI }\end{array}$ & $\begin{array}{l}\text { Number of pregnancies } \\
(\boldsymbol{\%}) \mathbf{n}=\mathbf{3 4}\end{array}$ & $\begin{array}{l}\text { Pregnancy } \\
\text { rate }(\boldsymbol{\%})\end{array}$ \\
\hline $\mathbf{1 5}$ & 01 & 00 & 00 & 23 & $01(3)$ & 4 \\
\hline $\mathbf{1 5 - 2 0}$ & 24 & $01(4)$ & 4 & 51 & $08(23)$ & 15 \\
\hline $\mathbf{2 0 - 2 5}$ & 31 & $02(9)$ & 6 & 27 & $04(11)$ & 14 \\
\hline $\mathbf{2 5 - 3 0}$ & 61 & $05(23)$ & 8 & 51 & $07(20)$ & 13 \\
\hline$>\mathbf{3 0}$ & 143 & $13(61)$ & 9 & 91 & $14(41)$ & 15 \\
\hline Total & 260 & 21 & & 243 & 34 & \\
\hline
\end{tabular}

Table 9: Donor IUI.

\begin{tabular}{|lllllll|}
\hline Donor IUI & $\begin{array}{l}\text { Single } \\
\text { IUI }\end{array}$ & $\begin{array}{l}\text { Number of } \\
\text { pregnancies }(\%) \mathbf{n = 2 1}\end{array}$ & $\begin{array}{l}\text { Pregnancy } \\
\text { rate }(\%)\end{array}$ & $\begin{array}{l}\text { Double } \\
\text { IUI }\end{array}$ & $\begin{array}{l}\text { Number of pregnancies } \\
(\%) \mathbf{n = 3 4}\end{array}$ & $\begin{array}{l}\text { Pregnancy } \\
\text { rate }(\%)\end{array}$ \\
\hline $\begin{array}{l}\text { AIH } \\
\text { husband }\end{array}$ & $197(75)$ & $12(58)$ & 6 & $176(72)$ & 19 & 10 \\
\hline AID donor & $63(25)$ & $9(42)$ & 14 & $67(28)$ & 15 & 22 \\
\hline Total & 260 & 21 & & 243 & 34 & \\
\hline
\end{tabular}

\section{DISCUSSION}

IUI is a widely available and relatively inexpensive treatment modality. The procedure is recommended for couple with the female partner having at least one permeable fallopian tube, sperm count above 5 million $/ \mathrm{ml}$ and corrected hormonal profile. Various prognostic factors have been studied. Namely age of the female partner, semen characteristics, duration of infertility and adequacy of stimulation, affect the outcome of the procedure. ${ }^{3}$
With ageing there is a physiological decrease in fertility. Reproductive ageing of gamete is a known entity. There is a reduction in potential of both male and female germ cells. This may be due to ageing of reproductive organ and cumulative changes or insult during spermatogenesis. In the female partner as the ovarian pool of germ cells depletes chances of successful pregnancy decreases. This may be reflected by ultrasound evidence of decrease in pool of antral follicles, supported by a decline in chemical indicators like $\mathrm{AMH}$ and increase in follicle-stimulating hormone (FSH) and luteinizing hormone (LH). ${ }^{4}$ 
This physiological decline is reflected in our study also. We saw a drastic reduction in pregnancy rate beyond age $35 y$. This was evident in both single and double IUI. In the age group of 30-35 years, success rate of single and double IUI are 42 and $35 \%$ respectively whereas the same falls to 9 and $6 \%$ of overall success in the age group 35-40 years. Other studies also support women age as the strongest predictor for success of IUI. Mervie et al saw that pregnancy rate falls four fold in ladies above age $40 \mathrm{y}$ as compared to women below 30 years. $^{3}$

Immediate et al did an exhaustive assessment of data over 21 years. They found that women below 35 years had a pregnancy rate of $11 \%$ as compared to $7 \%$ for ladies aged 40 years and above. In this retrospective observational study of 6323 IUI cycle's maternal age and day 3 FSH were found to be the only significant prognostic indicator of pregnancy rate (PR). ${ }^{5}$ In our study we saw a PR for the age category $30-35$ to be 14 and $12 \%$ for double and single iui as compared to 3 and $4 \%$ for ladies aged above 40 years.

Huyghe in a prospective cohort study of 1401 patients found obesity affecting fecundity adversely. An increase in weight leads to ovulatory and menstrual disturbance. Increase in BMI affects the germ cell health in both male and females. It depletes the fertilizing potential for both the sexes. This has been hypothesized due to altered gonadotropin pulse frequency. Obese and overweight ladies also had increased ovarian and adrenal androgen secretion. ${ }^{6}$ In our study we found highest PR in ladies with normal BMI. World Health Organization (WHO) recommends a normal BMI to be $20-25 \mathrm{~kg} / \mathrm{m}^{2}$. We saw maximum PR in this category for both single and double IUI. The PR was 29 and $13 \%$ respectively for double and single IUI. $70 \%$ of patient with successful IUI were in normal BMI range whereas only $3-4 \%$ of overweight couple could achieve a pregnancy with IUI.

Semen preparation in IUI aims to removes the seminal plasma, abnormal cells and defective spermatozoa. The process aims to make available the best cohort of spermatozoa available for fertilization. We used double density and swim up method of semen preparation. Boomsma in a randomized clinical trial (RCT) of various methods of semen preparation did not find any statistically significant difference in PR and miscarriage rate (MR). There is no specific recommendation for any particular method of sperm preparation. ${ }^{7}$

Because of lesser stimulation of ovaries IUI puts fewer burdens on the lady as compared to IVF-ET. Cost of individual cycle is less as compared to IVF-ET cycle thus less economic burden to the couple. Sirour evaluated more than 3000 procedures for various complications associated with IVF-ET. Surgical accidents/injuries and complications were found in 5\% of all cases of IVF-ET. Early pregnancy and obstetric complication included ectopic and heterotrophic pregnancy. Advanced pregnancy was compounded by multiple pregnancies and more incidences of low birth weight, preterm labor and gestational hypertension. ART procedure inherently includes psychological stress for the couple as well as socioeconomic problems. ${ }^{8}$

IVF-ET being a surgical procedure carries its own complications. Varied complication includes risk of hyper stimulation, injury to adjacent structures, potential for fertilization failure and side effect of intense luteal support. Thus it is felt that IUI is more patient friendly. Klemetti found an incidence of severe ovarian hyperstimulation syndrome (OHSS) as 1-4\%. He also found that risk of complication increases significantly over OI and IUI after repeated attempts. The incidence of admission for various morbidity increases to $15 \%$ in IVFET group as compared to $8 \%$ in OI group. ${ }^{9}$ We did not have any admission for complication of IUI-ovarian stimulation (OS) in our study. Our study also attests to the safety of IUI.

In our study the overall pregnancy rate was found to be 21 of 260 coming to $8 \%$ for single IUI and $13 \%$ for double IUI. This compares to various other studies. ${ }^{10}$

Ragni et al in a prospective randomized study evaluated 273 IUI cycles. They used clomiphene citrate (CC) and gonadotropin for stimulation. IUI were performed 12 and $34 \mathrm{~h}$ post trigger. ${ }^{11}$ The choice of stimulation and timing of IUI matches with our study. Similar to our study, they found a significant improvement in PR with double IUI.

Being less invasive and economic, double IUI needs to be explored more in selected subsets of infertile couples. Subit in a study of 1243 patients found double IUI to be significantly better in patient with endometriosis and antiendometrial antibodies. ${ }^{12}$ The study recommends double iui before resorting to more invasive and expensive treatment options.

Timing of performing double IUI has been debated. Silverberg in a randomized prospective study performed IUI in preovulatory that are 12 hours after ovulation trigger and second IUI after ovulation. ${ }^{13} \mathrm{We}$ followed similar timing. He also found a higher cycle fecundity rate comparable to our study.

With a history of previous conception the success rate of IUI increases as compared to that of couple with primary infertility. Various studies attest that any previous conception is a good prognostic factor for success with IUI. A previous pregnancy proves the fecundity of genital system as a whole. Dinelli et al in an analysis of 2019 cycles found pregnancy rate of about $14 \%$ in secondary infertility patients as compared to $8 \%$ in couples with primary infertility. ${ }^{14}$ This applies to both male and female infertility. The chance of clinical pregnancy was 3.605 times higher in men with secondary infertility. ${ }^{15}$

In our study we saw that $80 \%$ of all conceptions in both single and double IUI occurred in couples with secondary 
infertility. With increase in number of cycles the success rate falls. In our study the maximum chances of success occurs in the first cycle. There was a drastic reduction in chances of success with history of previous 3-4 IUI done. With an increase in duration of infertility there is an inverse relation with success in IUI. In couples with less than 5 years of infertility the success rate was about 61 and $50 \%$ for double and single IUI respectively, whereas the same falls to 9 and 7 after 10 years of duration of infertility.

Delgadillo et al in a retrospective analytic study of 668 IUI cycles found that greatest chances of success occur in patients with less than 4 years of duration of infertility. ${ }^{16}$ Maximum probability of conception occurs in first two cycles. The findings are in concurrence with our study.

Semen characteristics like prewash count, motility and post wash parameters all affects the success rate of IUI. Sakhel in a study of 1656 IUI cycles found that pregnancy rate for post wash sperm count of more than 20 million $/ \mathrm{ml}$ to be double that for count less than 5 million $/ \mathrm{ml} .{ }^{17}$ Ibérico et al found that compared with the insemination with a sperm count more than 30 million/ml to less than 5 million/ml, pregnancy rate fell from $15 \%$ to $4 \% .^{1}$ Our study showed a PR of 9 and $12 \%$, for single and double IUI respectively for sperm count more than 30 million.

Opponents of double IUI site need for a second visit, logistics of repeat sample preparation and attendant cost over single IUI. But the overall cost of achieving a pregnancy is lesser than IVF-ET cycle. Subtle abnormality of semen parameter affects $30-50 \%$ of couple. In these cases of idiopathic asthenozoospermia or oligozoospermia double IUI may be helpful. The hypothesis is based on making more number of healthier spermatozoa at the site of fertilization. Double insemination also counters the cervical and immunological factors affecting fertility. ${ }^{18}$ In our study there was a definite improvement in subtle male factor infertile couples with double insemination. Pregnancy rate for a prewash sperm count of 15-20 million was $23 \%$ in double insemination cycles as compared to $6 \%$ in single insemination cycles.

Zarek in a study of 2486 patients did not find a statistical significant difference in donor IUI cycles for double or single IUI. ${ }^{19}$ Chavkin in a retrospective study of over 300 IUI donor sperm cycles saw an average pregnancy rate over 3 cycles of $10 \%, 15 \%$ and $13 \%$ for single IUI, IUI with cervical insemination and double IUI respectively. ${ }^{20}$ In our study we found a pregnancy rate of $22 \%$ for double IUI and $14 \%$ for single IUI in donor sperm cycles.

Liu in a study of 1257 patients achieved a pregnancy rate of $11 \%$ for single IUI and $19.87 \%$ for double IUI. The study included mild male factor $15-20$ million $/ \mathrm{ml}$ and moderate male factor with sperm count of 10-15 million $/ \mathrm{ml}^{21}$

We have taken cut off for semen parameter as above 10 million/ml and progressive motility above $32 \%$. In the category of prewash $15-20$ million/ml we got a PR of $17 \%$ and for a post was count of 15-20 million we got a PR of $15 \%$ in double insemination group. In the same category for single insemination we got a PR of 6 and $4 \%$ respectively. Our findings corroborates with this large randomized prospective study.

Randall in a study of 999 single IUI and 277 double IUI found a PR of $17 \%$ for double IUI versus $8 \%$ for single IUI in couples with borderline male parameters. ${ }^{22}$ In our study population we saw a PR of $6 \%$ versus $17 \%$ for prewash count of 15-20 million for single and double insemination respectively. Clearly showing benefit of double IUI.

Bahadur $\mathrm{G}$ et al conducted largest observational study in UK. It included all IVF and IUI done from 2012-16. They found a gradual increase in IUI success rate over time. IVF-ET remains most advanced and effective treatment option for infertile couples. But a selected cohort of patient was more likely to benefit from IUI cycles. ${ }^{23}$ In our study we saw a definite benefit for couples with borderline male factor infertility and for couples with less than 5 years of infertility.

The final conclusion was IUI success is much closer to IVF ET than previously reported. IUI procedure was found to have a lower risk of maternal and neonatal complication.

\section{Limitations}

Further follow up of IUI pregnancies was beyond the scope of study. Outcome of pregnancies, incidence of preterm, anomalies and obstetric aspects could be another independent study. Causes of infertility and their impact on treatment success needs to be evaluated.

\section{CONCLUSION}

In our study we saw that double insemination did improve pregnancy rate. In resource poor setting like our country, it is essential that we maximize the potential benefit of this widely available treatment modality. Being OPD based and with lesser spectrum of potential

We conclude that double IUI is an essential, economic and more patient friendly treatment option for selected subset of infertile patients. Before resorting to advanced, invasive and costly options it may be more prudent to invest in double IUI.

\section{ACKNOWLEDGMENTS}

Author would like to thank all the nursing staff, PG residents, interns and supportive staffs. The authors are really grateful to all the participating ladies who consented to be part of the study.

\section{Funding: No funding sources \\ Conflict of interest: None declared}

Ethical approval: The study was approved by the Institutional Ethics Committee 


\section{REFERENCES}

1. Ibérico G, Vioque J, Ariza N, Lozano JM, Roca M, Llácer J, Bernabeu R. Analysis of factors influencing pregnancy rates in homologous intrauterine insemination. Fertil Steril. 2004;81(5):1308-13.

2. Silverberg KM, Johnson JV, Olive DL, Burns WN, Schenken RS. A prospective, randomized trial comparing two different intrauterine insemination regimens in controlled ovarian hyperstimulation cycles. Fertil Steril. 1992;57(2):357-61.

3. Merviel P, Heraud MH, Grenier N, Lourdel E, Sanguinet P, Copin H. Predictive factors for pregnancy after intrauterine insemination (IUI): an analysis of 1038 cycles and a review of the literature. Fertil Steril. 2010;93(1):79-88.

4. Vollenhoven B, Hunt S. Ovarian ageing and the impact on female fertility. F1000Res. 2018;7:F1000.

5. Immediata $\mathrm{V}$, Patrizio $\mathrm{P}$, Parisen Toldin $\mathrm{MR}$, Morenghi E, Ronchetti C, Cirillo F, Baggiani A, Albani E, Levi-Setti PE. Twenty-one year experience with intrauterine inseminations after controlled ovarian stimulation with gonadotropins: maternal age is the only prognostic factor for success. J Assist Reprod Genet. 2020;37(5):1195-201.

6. Huyghe S, Verest A, Thijssen A, Ombelet W. Influence of BMI and smoking on IUI outcome with partner and donor sperm. Facts Views Vis Obgyn. 2017;9(2):93-100.

7. Boomsma CM, Heineman MJ, Cohlen BJ, Farquhar C. Semen preparation techniques for intrauterine insemination. Cochrane Database Syst Rev. 2007;(4).

8. Serour GI, Aboulghar M, Mansour R, Sattar MA, Amin Y, Aboulghar H. Complications of medically assisted conception in 3,500 cycles Fertil Steril. 1998;70(4):638-42.

9. Klemetti R, Sevón T, Gissler M, Hemminki E. Complications of IVF and ovulation induction. Hum Reprod. 2005;20(12):3293-300.

10. Iberico G, Vioque J, Ariza N, Lozano JM, Roca M, Liacer J, Bernabeu R. Analysis of factors influencing pregnancy rates in homologous intrauterine insemination. Fertil Steril. 2004;81:1308-13.

11. Ragni G, Maggioni P, Guermandi E, Testa A, Baroni E, Colombo M, Crosignani PG. Efficacy of double intrauterine insemination in controlled ovarian hyperstimulation cycles. Fertil Steril. 1999;72(4):61922.

12. Subit M, Gantt P, Broce M, Seybold DJ, Randall G. Endometriosis-associated infertility: double intrauterine insemination improves fecundity in patients positive for antiendometrial antibodies. Am $\mathbf{J}$ Reprod Immunol. 2011;66(2):100-7.

13. Silverberg KM, Johnson JV, Olive DL, Burns WN, Schenken RS. A prospective, randomized trial comparing two different intrauterine insemination regimens in controlled ovarian hyperstimulation cycles. Fertil Steril. 1992;57(2):357-61.

14. Dinelli L, Courbière B, Achard V, Jouve E, Deveze C, Gnisci A, Grillo JM, Paulmyer-Lacroix O. Prognosis factors of pregnancy after intrauterine insemination with the husband's sperm: conclusions of an analysis of 2,019 cycles. Fertil Steril. 2014;101(4):994-1000.

15. Zarinara A, Zeraati H, Kamali K, Mohammad K, Rahmati M, Akhondi MM. The Success Rate and Factors Affecting the Outcome of Assisted Reproductive Treatment in Subfertile Men. Iran J Public Health. 2020;49(2):332-40.

16. Barros DJC, Rojas RJC, Molina MAC, Villalobos AS, Sánchez SV, Barroso VG, Gaviño GF. Prognostic factors of pregnancy in intrauterine insemination. Ginecol Obstet Mex. 2006;74(12):611-25.

17. Sakhel K, Schwarck S, Ashraf M, Abuzeid M. Semen parameters as determinants of success in 1662 cycles of intrauterine insemination after controlled ovarian hyper stimulation. Fertil Steril. 2005;84:248-9.

18. Zavos A, Daponte A, Garas A, Verykouki C, Papanikolaou E, Anifandis G, Polyzos NP. Double versus single homologous intrauterine insemination for male factor infertility: a systematic review and meta-analysis. Asian J Androl. 2013;15(4):533-8.

19. Zarek SM, Hill MJ, Richter KS, Wu M, DeCherney $\mathrm{AH}$, Osheroff JE, Levens ED. Single-donor and double-donor sperm intrauterine insemination cycles: does double intrauterine insemination increase clinical pregnancy rates? Fertil Steril. 2014;102(3):739-43.

20. Chavkin DE, Molinaro TA, Roe AH, Sammel MD, Dokras A. Donor sperm insemination cycles: are two inseminations better than one? J Androl. 2012;33(3):375-80.

21. Liu W, Gong F, Luo K, Lu G. Comparing the pregnancy rates of one versus two intrauterine inseminations (IUIs) in male factor and idiopathic infertility. J Assist Reprod Genet. 2006;23(2):75-9.

22. Randall GW, Gantt PA. Double vs. single intrauterine insemination per cycle: use in gonadotropin cycles and in diagnostic categories of ovulatory dysfunction and male factor infertility. J Reprod Med. 2008;53(3):196-202.

23. Bahadur G, Homburg R, Bosmans JE, Huirne JAF, Hinstridge P, Jayaprakasan K, et al. Observational retrospective study of UK national success, risks and costs for 319,105 IVF/ICSI and 30,669 IUI treatment cycles. BMJ Open. 2020;10(3):e034566.

Cite this article as: Patil D. Single versus double intrauterine insemination to assess the relevance of double intrauterine insemination: a prospective, randomized multicentric study. Int J Reprod Contracept Obstet Gynecol 2021;10:2459-65. 